\title{
Rio de Janeiro metrópole: arquitetura e infraestrutura como suporte ao projeto do território
}

\author{
Pedro Barreto de Moraes
}

Doutorando pelo Programa de Pós-Graduação em Urbanismo (PROURB-UFRJ), professor do Departamento de Arquitetura e Urbanismo da PUC-Rio e da Faculdade de Arquitetura e Urbanismo da Universidade Federal do Rio de Janeiro (FAU-UFRJ)

Contato: pedrobarretodemoraes@gmail.com

\section{RESUMO}

Este artigo parte do entendimento do Rio de Janeiro enquanto metrópole plural, porém marcada por grandes desigualdades impostas por dinâmicas urbanas implementadas a partir do fim do século XIX a partes distintas de seu território e vinculadas a variadas representaçóes. Dinâmicas estas relacionadas a paradigmas desenvolvimentistas, expansão e otimização dos tempos de deslocamento, possibilitados por grandes obras infraestruturais. A prática do projeto, em arquitetura e urbanismo, surge, nesse contexto, como atuação capaz de subverter parâmetros e instrumentos promotores de expansão desenfreada, perda de identidade e indefinição formal. Tomam-se as infraestruturas, especialmente de mobilidade, enquanto oportunidade de abordagem ao problema, aptas a amparar e promover preexistências cujas potencialidades podem operar como alternativas ao já saturado e restrito Centro Metropolitano, através da discussão de estratégias projetuais que propiciem lidar com questôes físico-espaciais complexas e distintas dos paradigmas tradicionais de arquitetura e urbanismo.

Palavras-chave: Urbanismo, infraestrutura, estratégias projetuais, metrópole, Rio de Janeiro.

\section{ABSTRACT}

This article begins with the understanding of Rio de Janeiro as a plural metropolis, but marked by great inequalities imposed by urban dynamics implemented from the end of the nineteenth century to distinct parts of its territory and linked to various representations. These dynamics are related to developmental paradigms, expansion and optimization of the times of displacement, made possible by large infrastructural works. The practice of the project, in architecture and urbanism, appears, in this context, as an action capable of subverting parameters and instruments that promote uncontrolled expansion, loss of identity and formal indefinition. Infrastructures, especially mobility, are used as an opportunity to approach the problem, capable of supporting and promoting pre-existences whose potentialities can operate as alternatives to the already saturated and restricted Metropolitan Center, through the discussion of strategies designed to deal with physical-space complex and distinct from the traditional paradigms of architecture and urbanism.

Key-words: Urbanism, infrastructure, design strategies, metropolis, Rio de Janeiro. 


\section{Introdução}

O processo de formação da metrópole do Rio de Janeiro se caracteriza, historicamente, por privilégios destinados a uma porçáo restrita de seu território, em detrimento da esmagadora maioria de bairros ou regióes, localizados essencialmente nas regióes norte e oeste, pouco ou nada contemplados por projetos urbanísticos e equipamentos de caráter ou escala metropolitana.

Fortemente atrelado à implementação de infraestrutura de mobilidade, seu crescimento urbano se deu ora através da expansão contínua da malha central, ora pela ocupação de áreas distanciadas do núcleo, posteriormente fundidas à mancha construída. Marcada pela constante atualização de equipamentos ferroviários e rodoviários, além de alimentada por relações econômicas, paradigmas desenvolvimentistas e modelos canônicos, este tipo de rede infraestrutural contribuiu para o distanciamento das classes proletárias do Centro Metropolitano, a partir de finais do século XIX e começo do século XX. Segue, hoje, como instrumento de articulaçáo entre setores de transporte, o Estado e o mercado imobiliário (TORRES, 2017, p. 153), que impulsam a ocupação de terras baratas e distantes das centralidades existentes, reforçando a expansão e a desigualdade impostas a partes distintas de seu território.

Apesar da exclusão, material e simbólica, da maior parte de sua área e população, de um ideal forjado de representação, a metrópole se desenvolveu, ao longo do tempo, de forma polinuclear, marcada por multiplicidade de tipologias, identidades e estilos de vida, não necessariamente alinhados aos padrôes prevalentes. Bairros e ocupaçóes preexistentes, fruto deste processo, possuem suas idiossincrasias, qualidades, problemas e potencialidades a serem estudadas e ex- ploradas; cultura, paisagem, lazer, história, economia e mais uma gama de possibilidades podem fomentar a autonomia de regiôes não subordinadas à concepção de um Rio de Janeiro excludente, limitado à porção de terra próxima ao mar.

Este trabalho propóe que as infraestruturas de mobilidade, por seu estreito vínculo com a formação da metrópole e o potencial que oferecem de acessibilidade e flexibilidade de utilização, podem servir como suporte a uma maior distribuiçáo de equipamentos urbanos, em geral restritos às classes de maior poder econômico e seus domínios. Isto implica, para longe da construção de mais vias, abertura de novos eixos especializados e um urbanismo baseado em paradigmas utilitários preconcebidos, que se pense no aproveitamento de um arcabouço que a própria cidade oferece e na integraçáo ao tecido e às dinâmicas urbanas já estabelecidos.

No âmbito da arquitetura e do urbanismo, esta possibilidade requer uma atitude menos apoiada sobre modelos, planos ou normas, e mais projetiva, o que não significa atuar de forma autônoma ou ignorar os grandes autores e matrizes destas disciplinas. Significa, sim, articulá-los a contextos, limitaçôes e oportunidades reais, buscando-se operar através de conceitos compartilhados que permitam reconhecer e apreender a complexidade do território e dos fenômenos que o caracterizam, dentre os quais exercem papel definitivo as infraestruturas de mobilidade e seus reflexos diretos, representados por terminais de transportes, grandes alças viárias, vazios, cruzamentos e interseçóes entre redes, enclaves de naturezas diversas, obras de engenharia e todo um catálogo de episódios a serem observados. 
É nesta chave que se investigam questôes relativas à forma urbana a partir do diálogo com preexistências e suas condiçóes determinantes, pensadas dentro do campo da arquitetura e confrontadas à cidade contemporânea naquilo a que Stan Allen se refere como um "urbanismo infraestrutural" (1999b) ou uma abordagem infraestrutural da paisagem (2010) e que Fernando Ramírez (2015) sugere como "um entendimento infraestrutural do projeto arquitetônico".

\section{Infraestrutura e forma urbana}

Por infraestrutura, entende-se aqui o conjunto de dispositivos que possibilitam a expansão de ocupaçôes urbanas, o percurso - otimizado e automatizado - das enormes distâncias que as separam e o estabelecimento de relaçóes de naturezas múltiplas mediadas por tecnologias da informação e comunicação. Os modelos e agentes cujas ideias urbanísticas se centram nestes aparatos, nas reformas e ampliaçóes são muitos e podem ser relacionados a partir de abordagens, interpretaçóes e recortes variados. Aqui interessa um entendimento morfológico dos processos de crescimento e tipos de ocupaçôes direta ou indiretamente relacionadas a eles.

Com base na Teoria Geral da Urbanização (1867), de Ildefons Cerdà, a cidade desordenada e insalubre deveria ser pensada e desenvolvida enquanto sistema e estruturada em rede, de acordo com o modelo do gridiron: uma malha ortogonal homogênea, expansível em todas as direçóes a partir dos limites simbólicos e monumentais de seu centro histórico fundacional. Pier Vittorio Aureli (2011) comenta que o lugar dessa cidade ordenada e unificada pela malha eram os subúrbios, cuja materialização não possuiria qualquer função representativa e criaria as condiçóes ideais para a reprodução da força de trabalho operária, em sua lógica expansionista e administrativa, cuja produtividade e movimento contínuo seriam capazes de metabolizar a tudo e a todos através de um processo de constante adaptação e autopreservação.

Albert Pope (1996) destaca que o gridiron, modelo de crescimento urbano centrífugo, é um agente de simplificação e ao mesmo tempo de diversidade; previsível e indeterminado, prescritivo, porém ambíguo. Enquanto sistema oferece enorme interconectividade e flexibilidade, mas perde em eficiência, se comparado ao modelo ferroviário que, separado do tráfego e segregado do tecido urbano, acelera os deslocamentos e as relaçóes comerciais.

$\mathrm{O}$ advento do transporte e da infraestrutura ferroviária estimula, nos séculos XIX e XX, a formação de subúrbios, situados para além dos limites das ocupações urbanas de então, alimentando ideias e modelos que dialogam com o de Cerdà e se pretendem universais. A cidade jardim, de Ebenezer Howard e a cidade linear, de Arturo Soria y Mata, guardadas suas diferenças, tinham em comum o caráter sistêmico, a busca pelo espaço integrado, marcado por intençôes democráticas e uma soma de metas ideologicamente afins, ditas: "crescimento urbano, adensamento, movimentação de pessoas e mercadorias [...] e posição relativa das funções e modos sociais de ocupar a cidade”, traduzidas e viabilizadas a partir da abertura de grandes vias, propagação de infraestruturas e a reformulação de tecidos antigos (FEFERMAN, 2007, p. 34).

Embora conjugassem os modais rodoviário e ferroviário em seus modelos, traziam, na possibilidade de transposição dos limites urbanos e na conquista de territórios intocados, um reflexo dos avanços tecnológicos daquele tempo, que vieram a influenciar a urbanização, direta e indiretamente, em todo o 
mundo. O modelo de Howard foi desdobrado em configuraçóes polinucleares, geradas a partir de centralidades suburbanas e estações ferroviárias, como Bedford Park, em Londres, Frohnau, em Berlim (HAUCK; KLEINEKORT, 2011, p. 12) e os bairros da Leopoldina, no Rio de Janeiro ${ }^{1}$. As ideias de Soria y Mata, por sua vez, influenciaram teóricos como Ludwig Hilberseimer e Le Corbusier, resultando, em última análise, no que Pope chamou de ladder: um sistema centrípeto ou fechado, oposto ao que seria o gridiron do século XIX, centrífugo, de crescimento infinito. Este mecanismo se caracteriza pela erosão da malha (griderosion) e por uma inundação de espaço (inundation of space) sobre as cidades, representadas sob a figura de gigantescos vazios pontuados por construçôes isoladas, que interrompem a conectividade e flexibilidade do grid e polarizam duramente o ambiente urbano.

A erosão do grid cessa a continuidade do que antes, de maneira simplificada, porém clara, se configurava como um arranjo entre espaço e forma. Esta interrupção não é preenchida nem ocupada, mas apenas dissipada por mais espaço livre, e a configuração resultante é o diagrama de relaçóes do ladder $^{2}$, uma figura formada por um eixo linear, a partir do qual se destacam afluentes ou "degraus", fechados sobre si mesmos que podem ser, eventualmente, resquícios de uma malha outrora contínua que resulta obstruí$\mathrm{da}$, descontinuada. Aos espaços residuais, externos a esta formação, o autor denomina elipses, inevitáveis subprodutos do desenvolvimento centrípeto, aquilo que sobra entre eixos viários e enclaves fechados sobre si próprios, em permanente estado de desorganização, de entropia ${ }^{3}$, por distinção a seu oposto. São áreas sem forma, sem nome, invisíveis - aquelas que, em um ensaio de aproximação a estes fenômenos, Ignasi de Solà Morales (2002) denominou terrain vague.
Pope avança, em sua análise, sobre o que Christopher Alexander (1965) definiu como configuração de cidade "em árvore", determinada por uma gradação hierárquica de vias que vão desde as grandes expressas, de intenso fluxo, velocidade e calibre, até vias locais, de proporçôes e velocidade reduzidas. A ocupaçáo determinada por este desenho e pela infraestrutura rodoviária é, em geral, muito mais flexível e capilar que a ferroviária, dependente de núcleos periodicamente espaçados. É esta flexibilidade que proporciona situaçóes híbridas, nas quais eixos de alta performance se justapóem ou sobrepóem a redes mais lentas, de menor calibre ou urbanização precária (HAUCK; KLEINEKORT, 2011, p. 14; IZAGA, 2009, p. 65), associando-se a áreas marcadas pela informalidade e concentradas especialmente no hemisfério sul, representadas por mais de 30\% da população urbana no mundo (WERTHMANN, 2011, p. 290). Esta população, via de regra, trabalha e reside em localizaçôes muito distantes entre si, dependendo enormemente dos meios de transporte vinculados às grandes infraestruturas de mobilidade para se locomover.

O acúmulo de camadas derivadas de modelos urbanísticos e as ocupaçóes atreladas a estes configuram o cenário das grandes metrópoles contemporâneas, onde informalidade, sobreposiçôes de usos, rupturas de escala e fragmentos isolados, frequentemente "sobrevoados por grandes infraestruturas de transporte" (LASSANCE; IZAGA, 2009, p. 54) convivem com o espraiamento de unidades residenciais em meio ao ritmo frenético da circulação, da produtividade e da repetição. A estabilidade do objeto arquitetônico tradicional não dá conta da complexidade de tais fenômenos que, dinâmicos e transitórios, se influenciam mutuamente e compóem um todo disforme e indefinido. Stan Allen (ALLEN, 1999a) sugere que, se 
pensarmos na noção de figura, não como objeto definido contraposto a um campo ${ }^{4}$, mas como um efeito que emerge do próprio campo como momento de intensidade ou distensão, podemos nos aproximar do entendimento de uma condição metropolitana em que o infraestrutural surge como sistema capaz de articular as relaçóes entre as partes que formam o território sem, no entanto, condicioná-las por uma totalidade predefinida.

\section{Cidades dentro da cidade}

A concepção de território cujas partes se influenciam reciprocamente e modificam um todo flexível remete a um projeto que, ao invés de planejar a cidade integralmente, aplicar normas ou investir sobre áreas previamente privilegiadas, procurou potencializar o processo dialético da contraposição de fragmentos distintos. The City in the City - Berlin, a Green Archipelago (1977 - Figura 1), idealizado por Oswald Mathias Ungers e uma equipe de arquitetos ${ }^{5}$, buscou, diante da instabilidade vigente, contexto de crise e esvaziamento iminente ${ }^{6}$, pontuar a cidade com intervençôes diferenciadas. Para Ungers, essa abordagem poderia superar a fragmentaçáo, fazendo da crise em si - a impossibilidade de planejar Berlim - a oportunidade para se reforçar a forma urbana (AURELI, 2011, p. 178).

O trabalho resultou de vastas pesquisas realizadas com a participação de estudantes e foi apresentada a um comitê do SPD (Partido Social - Democrata da Alemanha) como modelo alternativo para a cidade. Àquela época, um ideário focado na renovação e revitalização já se fazia presente e o arquipélago, contrário a ele, propunha suas "ilhas" em meio a grandes áreas verdes e infraestruturas, evitando a diluição e a homogeneização do espaço e visando realçar o ca- ráter culturalmente múltiplo de "cidades dentro da cidade"7 (HERTWECK; MAROT, 2013).

Análoga à ideia do arquipélago, porém anterior, é a de "constelação de núcleos" (Constellation of Cores, 1951), de Jacqueline Tyrwhitt, que pretendia, no âmbito metropolitano, dar forma ao tecido construído e preexistente, a partir de momentos de adensamento e reconhecimento das identidades correspondentes às diferentes partes componentes de um todo em constante processo de expansão. Contrária ao programa das "novas cidades" (new towns), implementado no Reino Unido do pós-guerra (SHOSHKES, 2009) e pensada diferentemente de proposiçóes como a Garden City, de Howard, ou o próprio Green Archipelago, de Ungers, que se instalariam em meio a amplos espaços livres, a "constelaçáo" de Tyrwhitt deveria inserir-se em meio aos subúrbios já construídos, diferenciando-se por maior densidade e programas articulados às características específicas de cada localidade (D'HOOGHE, 2010).

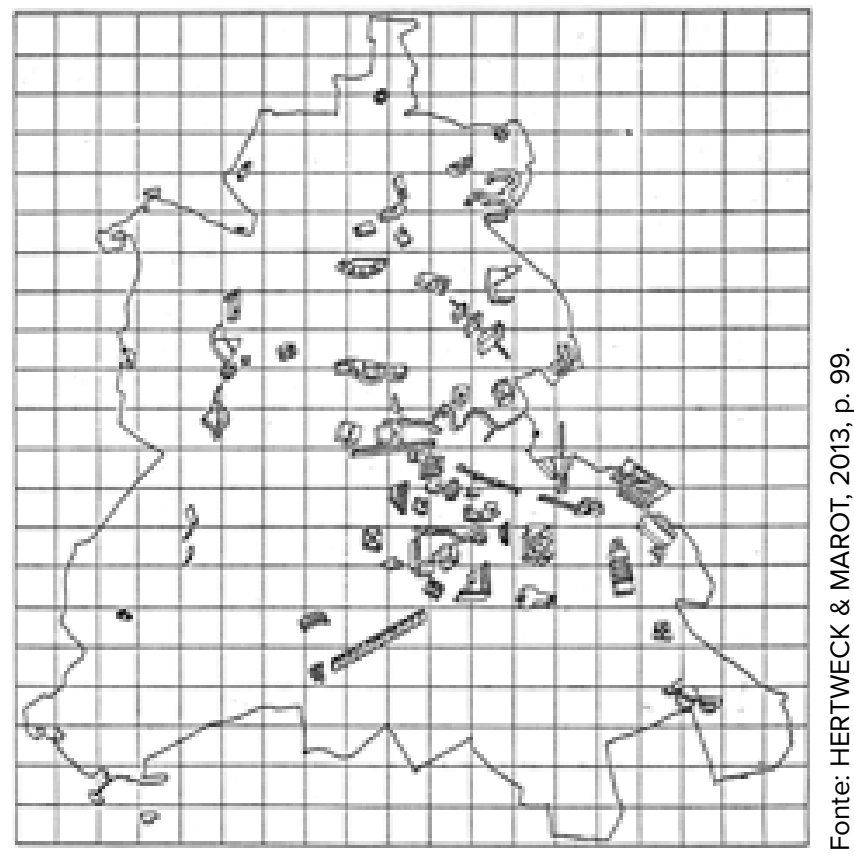

Figura 1: Oswald Mathias Ungers, Rem Koolhaas, Peter Riemann, Hans Kolhoffe Arthur Ovaska. Berlin as a Green Archipelago, 1977. 
Mais que soluçóes projetuais, esses trabalhos interessam por demonstrarem a possibilidade de diálogo com o existente, na busca por compreender e tomar partido das condiçóes que a cidade oferece e realçar aspectos presentes nas diferentes formas, paisagens e culturas metropolitanas. Aureli (2012, p. 26) relaciona estas contingências à ideia de "singularidade do locus", conforme Aldo Rossi: uma estrutura oculta, relacionada ao comum, à potencialidade que cada lugar, a partir de sua coletividade apresenta, como uma instância enraizada, cujo potencial pode ser atualizado e materializado física, espacial e construtivamente.

A ideia de "cidades dentro da cidade", aqui mencionada no âmbito da arquitetura e do urbanismo, foi utilizada também pelo cronista Marques Rebelo para referir-se ao Rio de Janeiro, segundo o historiador Luiz Antônio Simas (2016), que endossa este entendimento ao afirmar que "cada uma destas cidades tem seus espaços de construção de memórias e desenvolve formas peculiares de experimentar a vida $\mathrm{e}$ abordar o mundo". Simas define como cultura o tipo de prática e concepção simbólica que, segundo ele, "não é naturalmente coisa boa ou ruim", mas sim "a maneira como um grupo reelabora formas de vida e estabelece significados complexos sobre a realidade que o cerca”. Esta visão dialoga com o que nos comenta Márcia Ferrán (2009, p. 90) sobre os diferentes bairros ditos suburbanos, no Rio de Janeiro, como espaços de "junçáo da diversidade e dos desafios da alteridade", onde se fermentam inovaçóes e reinvençôes na busca por melhores condiçóes de vida, configurando-se em "espaço-chave, tanto para o urbanista quanto para o antropólogo" 8 .

A leitura de Simas e Ferrán serve como contraponto à amplamente disseminada diferenciação imposta a parcelas distintas da cidade do Rio de Janeiro, cons- tatável, por exemplo, no que se entende por "conceito carioca de subúrbio" (SOARES, 1965 apud FERNANDES, 2011, p. 33), relacionado à promoção de parte de seus bairros como lugar do proletariado, à época das reformas urbanas de finais do século XIX e início do século XX, e sua associação a uma simbologia pejorativa e inferiorizada, sempre dissociada da imagem relativa aos bairros ditos nobres.

Lugares mais abastados, mesmo situados a distâncias consideráveis do centro e espacialmente configurados conforme o que tradicionalmente se pode entender por subúrbio9, se fizeram vincular às elites econômicas e dissociar das classes populares. Ocupaçóes adjacentes ou próximas à regiáo central e pioneiras da urbanização brasileira se ligaram à construção de uma simbologia subordinada, estigmatizada, carente de equipamentos urbanos, historicamente atrelada aos vetores de expansão das infraestruturas de mobilidade ferroviária, primeiramente, e rodoviária, em seguida, rumo ao norte e oeste da cidade. Apesar de serem, hoje, parte consolidada da mancha relativamente densa e contínua de bairros, estas ocupaçóes sofrem as consequências de gradativo abandono e identificação com o rótulo de periferia (LINS, 2009; OLIVEIRA, 2015) ${ }^{10}$.

O viés político desta distinção é reforçado quando se observa a destinação de áreas de orla oceânica, porém afastadas do Centro Metropolitano, ao turismo e habitação de classes de alto poder aquisitivo e a expansão desordenada de áreas dormitórios ou industriais, pouco privilegiadas por políticas públicas e ausentes da representação de um ideal notadamente parcial de cidade, em sentido oposto. O fenômeno se amplifica pela prioridade dada à regiáo portuária, no Centro, e às áreas da Barra da Tijuca e da Baixada de Jacarepaguá, na zona oeste, no que corresponde a investimentos voltados aos megaeventos recentemente 
realizados. Infraestruturas, equipamentos esportivos, culturais e obras de mobilidade urbana se somam a generosos incentivos fiscais e investimentos concentrados, essencialmente, na porção geográfica situada entre o mar e os maciços da Tijuca e Pedra Branca (NOBRE, 2015). À exceção da área de Deodoro, que confirma a regra ${ }^{11}$, um processo de considerável crescimento intensificou, desde 2009, com o anúncio do Rio de Janeiro como sede dos Jogos Olímpicos, o já notável deslocamento populacional rumo à planície oceânica da Barra, impulsionado pelo mercado imobiliário. Mercado este que, atraído pela perspectiva de maximização de seus lucros, investiu e investe em terrenos de baixo custo localizados em áreas desvalorizadas, marcadas pela informalidade, carência de infraestrutura sanitária e acessibilidade, às quais se faz aderir, institucional ou informalmente, uma imagem estereotipada, que se acresce à ausência contínua de investimentos complementares ao restante da cidade (LASSANCE, 2017).

Este modelo denota o isolamento voluntário, constatado por Flávio Villaça (2001), de nossa elite econômica, tomadora de decisôes e, além de desigual e segregado, revela-se também inviável. A insistência em se concentrar intervençôes urbanas sobre parcelas historicamente privilegiadas do território, em detrimento de regiôes alternativas, se reflete nas inimagináveis horas de deslocamento casa/trabalho enfrentadas por residentes da cidade e municípios vizinhos da regiáo metropolitana em dias de semana, nos colossais engarrafamentos registrados nas vias de conexão e no inchaço diário provocado pela concentração de empregos e serviços na cidade do Rio de Janeiro, especialmente na área central (SEBRAE, 2013). É evidente que se espera transporte público de qualidade e acessível a toda a populaçáo, mas a repetida atualização de modelos robustos e onerosos de mo- bilidade não será suficiente para suportar o constante incremento de demanda. A sobrecarga sobre os modais, especialmente em horários de pico, e a aposta em modelos calcados na abertura de novos corredores expressos e estaçóes monofuncionais parecem ignorar o fato de que a construçáo de novas vias tende a aumentar a solicitação e a quantidade de veículos sobre o sistema (SOLOMON, 2004, p. 31), além de reiterar a ausência de espaços de escala e envergadura metropolitanas, nas zonas norte, oeste e Baixada Fluminense. Assim se perpetuam a polarizaçáo e dependência históricas entre uma região concentradora de equipamentos, serviços e investimentos, hipervalorizada, e um imenso território relegado à "segunda classe" - ao qual se prestam, quando muito, serviços básicos - cuja importância política, cultural e histórica é continuamente desvalorizada e cujo potencial estruturante sobre o território da cidade é mantido constantemente subaproveitado.

\section{Por um pensamento projetual}

Seguindo aquela lógica, as recentes políticas e projetos de escala ou envergadura urbana no Rio de Janeiro se resumem basicamente a dinâmicas tecnocráticas, frequentes atualizações de equipamentos de mobilidade, abertura e ampliaçáo de vias expressas, expansão territorial principalmente rumo a oeste e revitalizaçôes do centro consolidado, por meio de práticas cuja condução e execução têm sido, minimamente, questionáveis, por sua celeridade e falta de transparência. Entre os interesses do mercado e a defesa do modelo de cidades compactas, difundem-se novos eixos viários, distritos de negócios e intervençôes faraônicas destinadas a apagar os vestígios do desenvolvimento de outrora, como as obras de derrubada do Elevado Juscelino Kubitschek - popularmente conhecido como Elevado da Perimetral 
- e construção do túnel Marcello Alencar, parte da operaçáo Porto Maravilha ${ }^{12}$. Este exemplo guarda similaridades com outra gigantesca e não menos controvertida intervenção, realizada em Boston: o $B i g-D i g^{13}$, megaprojeto de escavação na regiấo central, que direciona ao subsolo o tráfego rodoviário e parece, apesar das cifras exorbitantes, atrasos e pouca participação da sociedade sobre a tomada de decisões, fazer parte do ideário que influenciou a condução das reformas cariocas, segundo o qual se abre mão de esforços ou estratégias voltados à integração da infraestrutura às demais camadas e fenômenos urbanos - alguns recorrentes de adaptaçóes realizadas pela própria populaçãa ${ }^{14}$ - optando-se por seu apagamento ou invisibilidade.

Além dos montantes injustificáveis movimentados por estas operaçôes, é preocupante constatar que se tratam de atuaçôes fundadas sobre a escassez de diálogo e críticas genéricas a paradigmas atribuídos ao modernismo e obras resultantes de práticas características do capitalismo tardio. Somada à apologia de lugares e qualidades estéticas das cidades tradicionais - em geral inspiradas nos centros das principais capitais europeias - este tipo de atitude se pode relacionar ao que Pope (1996, p. 133), citando Fredric Jameson (1994), identifica como uma "crise de historicidade", caracterizada pela incapacidade de articulação entre um futuro a ser especulado, discutido, e camadas remanescentes de períodos históricos anteriores, sejam estas apreciadas ou não. Estas noçôes superficiais e redutoras se refletem em simulaçôes nostálgicas e rompimento com o real, resultando inócuas frente à complexidade da metrópole contemporânea e à busca de uma terceira via de projeto, situada entre os discursos paradigmáticos de cidades compactas $\mathrm{e}$ os modelos funcionais baseados em movimentação e espraiamento urbano.
Uma série de arquitetos da segunda modernidade ${ }^{15}$ procurou lidar com desafios colocados por configuraçôes de territórios em expansão e inundados por dispositivos voltados à circulação de bens e pessoas, a partir da segunda metade do século XX, buscando compreender as mudanças sociais, seus reflexos sobre as metrópoles em formação e encontrar estratégias projetuais em sintonia com cenários urbanos heterogêneos, dinâmicos, fortemente comunicados e velozes (RAMÍREZ, 2015). Estes autores olhavam para a cidade em crescimento, marcada por desenvolvimento econômico, invasão de infraestruturas e automóveis, com o intuito de orientar as transformaçóes em curso ao reconhecer seus agentes, sem recair em sua negação ou destruição (D'HOOGHE, 2010), oferecendo-nos, para além de ideias e conceitos instrumentais, a perspectiva do projeto enquanto processo exploratório de novos rumos para a arquitetura e a cidade contemporânea.

O projeto, neste sentido, entendido como atividade de pesquisa, especulativa e crítica, articulada à teoria, a partir da qual pode se orientar e operar para além do design, no âmbito da estratégia, construída sobre variados pontos de observaçáo de nossa condição (AURELI, 2015). Nesta tarefa, é preciso transitar entre tantos campos quantos forem necessários para que se amplie o espectro de reflexáo e se possa retornar ao âmbito da arquitetura e do urbanismo pela geração de conhecimento e formulação de conceitos experimentais, sem os quais o projeto se torna mera repetição de saberes domesticados, específicos e tecnocráticos, resolução de problemas sujeita a metodologias interdisciplinares pré-fabricadas, frequentemente apregoadas pelo mercado - que cria suas próprias demandas, solicitando especializaçóes a priori - e com as quais é preciso cautela. 
A aplicação de regras rígidas e descontextualizadas, orientadas por preceitos canônicos, não permite dar conta da complexidade típica de cenários onde fenômenos múltiplos se manifestam, se chocam, entrelaçam e se dispersam, criando matrizes de relaçóes para muito além das duas dimensôes do plano convencional. Diante desta dificuldade, o exercício da arquitetura recai frequentemente em condutas niilistas, procrastinaçáo e esquiva perante a "responsabilidade de dar forma ao espaço urbano" (FRAMPTON, 1996, p. 85), de designar novas relaçóes, propor desenhos e pensar arquitetonicamente, acabando por recorrer a instrumentos reguladores e normativos, consequente perda de contato com a realidade e subordinação $\mathrm{da}$ diversidade e multiplicidade inerentes às grandes cidades a dinâmicas sistematizadoras (KONDER, 2002). A sujeição da atividade crítica e especulativa de projeto a atores externos tem feito da arquitetura instrumento de mero embelezamento, decoração e mediação das tomadas de decisóes de gestores executivos e investidores, contribuindo para que se mantenham ou ampliem as condiçốes de cidades que conhecemos; no entanto, a compreensão de que a forma urbana, para muito além de uma existência determinante, absoluta e estável, é tradução da realidade política para o espaço (WOODS, 1975), pode impulsionar-nos à reflexão, ao questionamento dos modelos e organizações estabelecidos e à formulação de novas agendas, fundadas no "indispensável vínculo que a noção de projeto implica em termos de posicionamento crítico, pautado por um determinado conjunto de valores e ideais" (LASSANCE; ENGEL, 2016, p. 3), a partir dos quais se podem investigar maneiras estratégicas de atuação sobre o existente.

\section{Infraestrutura como estratégia}

Grandes infraestruturas fragmentam tecidos, "separando lados" e, na maioria das vezes, desintegrando malhas urbanas. Apesar de atuarem em favor da eficiência e otimização de longos deslocamentos, contribuem para o distanciamento de localizaçóes próximas. Além disso, costumam ser, apesar de absolutamente necessárias, indesejadas por aqueles que usufruem de seu funcionamento e, em geral instaladas em regióes periféricas, tratadas de maneira tecnocrática, utilitarista e monofuncional ${ }^{16}$. Associando-se a discursos progressistas, refletem tratamentos desiguais conferidos a diferentes áreas e suas populações, como resultado de práticas, intençóes, escolhas e prioridades conscientes daqueles que, historicamente, detém poder de decisão (D'HOOGHE, 2007, p. 433).

Sua operacionalidade e estreito vínculo com a noção de mobilidade devem se somar a uma consciência sobre sua perenidade e ao entendimento de que leituras cuidadosas podem revelar múltiplas características e especificidades definidoras de diferentes contextos e paisagens urbanas. Entre a produtividade, o utilitarismo e uma série de modelos inflexíveis, existe a cidade real, praticada e não institucionalizada (FARIAS FILHO, 2012), anônima, amorfa e invisível e talvez por isso mesmo, potente e sutil, vinculada à pluralidade de identidades e capacidade de reinvenção presentes em pontos de desligamento das lógicas funcionais, padróes de consumo e controle. Nestas frestas (SIMAS, 2016) ${ }^{17}$, fissuras ou interstícios, entendidos a partir de uma condição de ausência - que, conforme sugere Solà-Morales (2002), oculta possibilidades ensejadas por sua própria indeterminação - existe uma "potência evocativa" de encontro e de liberdade. Aí reside a oportunidade de aderência ao 
tecido urbano, de mescla e hibridismo entre o que é rígido e normativo e o que é contingente e imprevisível.

Nestes momentos, o infraestrutural pode atuar como suporte para configuraçóes e potencialidades preexistentes, reforçando representaçóes e paisagens não enquadradas sob os padróes dominantes. Esta maneira de enxergar as metrópoles contemporâneas em geral e, mais especificamente, o Rio de Janeiro, exige aprofundamento e compreensão sobre cada contexto; exige ainda que a prática projetual não acate dinâmicas impostas por agentes externos e que não se aceite unificar um território táo plural sob modelos pré-concebidos.

O que Fernando Ramírez (2015) sugere como um "entendimento infraestrutural do projeto arquitetônico" deve possibilitar a inserção e o diálogo do projeto em domínios consolidados ou em expansão, de maneira a articular transiçóes, interfaces e relaçôes de estímulo recíproco a suas "condições de campo" (ALLEN, 1999a - Figura 2), que podem ser quaisquer matrizes formais ou espaciais capazes de unificar diversos elementos, respeitando suas identidades, através das quais o infraestrutural se oferece como estratégia de abordagem projetual, tanto em escala territorial como local.

Em âmbito ampliado, trata-se de tomar partido do caráter tecnocrático, contínuo, perene e intersticial das redes que conectam e comunicam localizaçóes distantes, estabelecendo organizaçóes coletivas flexíveis, compostas por eventos pontuais em sequência, determinados a partir de "conjunçôes físicas, perceptivas ou culturais" (RAMÍREZ, 2015, p. 83) a serem potencializadas e mutuamente incrementadas por novos arranjos. Esta ideia se refere à possibilidade de influência recíproca e diálogo entre as partes que po- dem, de baixo para cima, modificar a noção de conjunto sem, no entanto, ter que atender a disposiçóes hierárquicas.

Em escala local, trata-se de compreender as frestas, fissuras e interstícios urbanos, gerados por grandes aparatos e obras infraestruturais, como possibilidades para o agenciamento de camadas e relaçóes, ora concretas, ora intangíveis, em momentos de intensificação de fenômenos dinâmicos onde, muito mais que determinaçôes formais, importam as formas "entre as coisas" (ALLEN, 1999a, pág. 92). Nestes episódios de convergência, as escalas, velocidades e os usos oscilam e se modificam, ao longo do tempo, e não se devem limitar por normas ou figuras rígidas, mas orientar por organizaçôes flexíveis, estratégias de transição e interface com preexistências, domínios consolidados ou em expansão. Esta busca, relacionada ao que Allen define como campo e confrontada à inevitável solidez da arquitetura, demanda a ideia de infraestrutura enquanto "estrutura aberta mínima” (TZONIS; LEFAIVRE, 1998, p. 21), primária, ou "a quantidade de arquitetura necessária para atuar como sistema suporte" (RAMÍREZ, 2015, p. 133), capaz de estabelecer um conjunto de regras segundo as quais se poderão manifestar eventos, relaçóes e experiências múltiplas, contingentes e indeterminadas, acomodadas por estruturas secundárias.

As qualidades de "abertura estrutural" e "arquitetura suficiente" se relacionam a espacialidades ou materialidades posicionadas para além da mera distinção entre interior/exterior ou da dicotomia horizontal/ vertical relativas, em geral, a formas unívocas e objeto isolados. Kengo Kuma, em Anti-Object (2008), atesta, a partir da análise de projetos nos quais tempo e espaço se mostram indissociáveis, a importância do elemento horizontal de piso (floor) e a possibilidade que este oferece de fruição espacial e temporal si- 

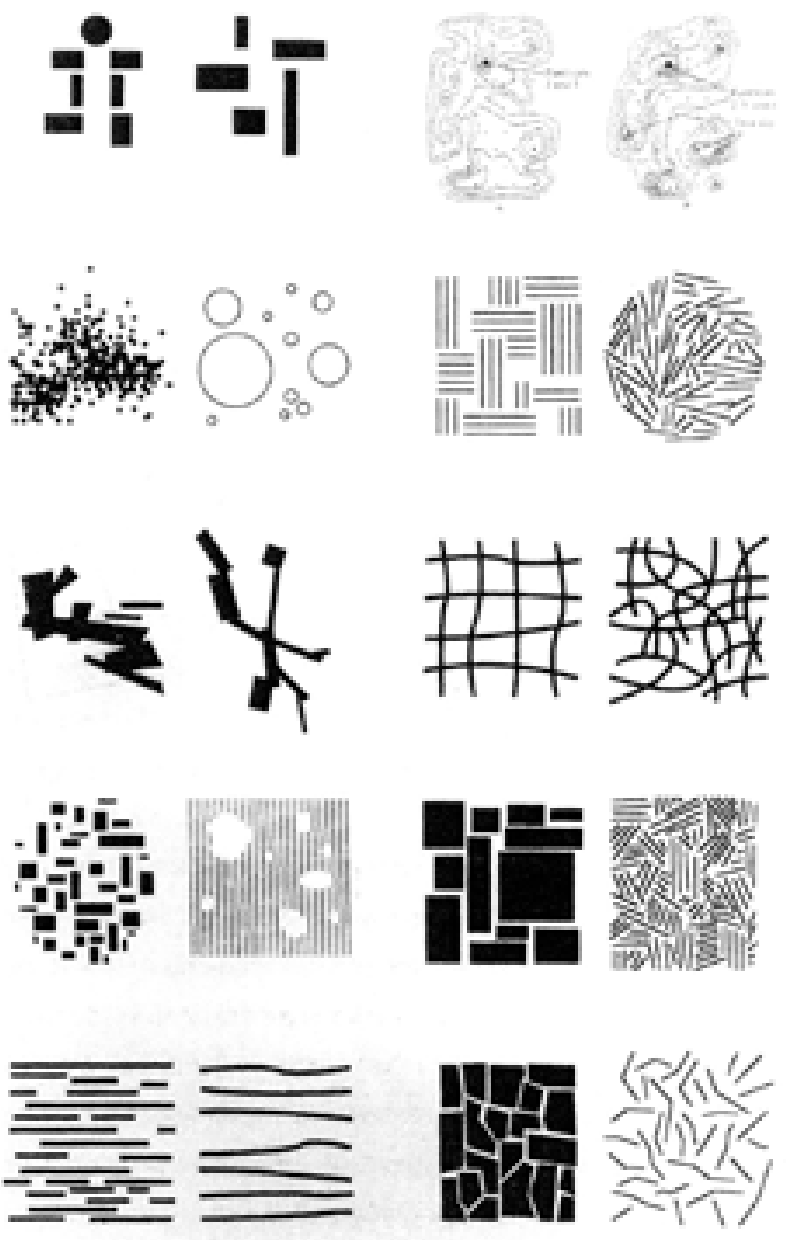

Figura 2: Stan Allen. Diagramas de condiçôes de campo.

multânea, à diferença da natureza vertical da parede (wall). Enquanto a última se percebe de maneira fixa e constante, o primeiro se desdobra progressiva e gradualmente através do deslocamento, evidenciando a essência do espaço - mais que como vazio, intervalo entre formas - enquanto "meio" entre sujeito e mundo, numa visão essencialmente relacional de possíveis recursos projetuais, a partir dos quais se podem vislumbrar associações, interaçôes e interlocuçôes estabelecidas por agentes, fenômenos ou eventos distintos, separados ou sobrepostos.
A investigação de Kuma dialoga com o que Fumihiko Maki e Jerry Goldberg (1964 - Figura 3) denominaram Linkage in Collective Form: um instrumento, uma estratégia flexível de atuação, que procura acomodar mudanças e que prescinde de geometrias definidas (D'HOOGHE, 2010), capaz de catalisar elementos separados e individualizados do espaço urbano, partindo da possibilidade de articular formas existentes através do projeto. A noçáo de linkage (ligação) referida não está associada estritamente à função de circulação, mas à potencialização de interstícios por meio da integração de camadas, associações, reorganizaçóes espaciais ou territoriais. As açóes de "mediação", "definição", "repetição", "criação de rotas" e "seleçãa" sugeridas pelos autores buscam propiciar a experiência de agrupamentos coletivos onde, mais que a específica determinaçáo formal ou a ideia de deslocamento linear, importam as relaçóes estabelecidas por partes ora desconexas.

Estas estratégias abrem mão de noções compositivas, experimentaçôes plásticas ou determinaçóes programáticas, que se aproximam de formas fechadas ou autorreferentes, em geral relacionadas a representações limitadas e relaçóes de poder tendentes a definir seus usos, separar os espaços de seus entornos e distanciá-los da convivência pública, fundada sobre o encontro, a interseção e o atrito (D'HOOGHE, 2010). Uma arquitetura sem pretensóes formais, em que o construído se preste a orientar relaçóes e articular camadas, admite o espaço urbano como soma de processos, cujo arranjo ou organização espacial será fruto de potencialidades motivadas por associaçóes não prescritivas, dispostas a absorver contingências e permitir dinâmicas imprevistas.

Partindo-se deste entendimento, obras de infraestrutura de mobilidade se oferecem como oportunidade para a articulação e redistribuição de fluxos advin- 
dos de diferentes direçóes ou situados em planos verticalmente separados. Permitem também pensar ações de enlace entre territórios segregados, além de abrirem possibilidades para o aproveitamento de superfícies inexploradas, ocultas sob a desarticulação entre grandes eixos ou nós viários e os tecidos aos quais cortam ou se sobrepóem. Ademais, seu grande dimensionamento estrutural, enormes vãos, pés direitos e desníveis, somados às qualidades construtivas de modularidade e padronização, permitem interpretá-las como sistemas suportes, capazes de atuar como receptáculos a variados repertórios de estratégias e açóes projetuais, destinadas a conectar e ativar espaços adormecidos sob lógicas tecnicistas, obtusas e restritivas.

\section{Aproximaçóes ao Rio de Janeiro}

Uma observação sobre a evolução da cidade e a formação da área metropolitana do Rio de Janeiro demonstra o quanto a rede de mobilidade, historicamente implementada com pouquíssima ou nenhuma aderência ao tecido urbano, salvo os pontos onde capta ou escoa seus fluxos, pode atuar como base a intervenções sobre ocupaçôes existentes, consolidadas ou em processo de consolidação, cuja origem e motor se deram justamente em estreito vínculo com a malha infraestrutural. Os modelos do gridiron mesmo que não ortogonais, mas contínuos -, o ferroviário e o rodoviário influenciaram determinantemente o crescimento da cidade, desde as primeiras expansôes, passando pela construção das estaçóes e centralidades da zona norte e posteriormente da zona oeste, até a profusão de avenidas, rodovias e vias expressas que marcam o substrato da metrópole.

Partindo da regiáo central, amplamente irrigada, as ferrovias conectam-se a variados pontos da Baixada Fluminense e Santa $\mathrm{Cruz}^{18}$, passando por inúme- ros bairros das zonas norte e oeste, enquanto que as vias expressas se ligam a estradas de alcance intermunicipal e interestadual ${ }^{19}$. À ocupação polinuclear principiada pelas estaçóes ferroviárias somam-se o caráter flexível e capilar promovido pelas rodovias e o enorme número de ocupaçóes informais, alimentadas pela expectativa da população de um mínimo de acessibilidade propiciada pela proximidade a estes eixos. Assim, um mosaico de tipologias e dispositivos orientados à expansão e circulação de pessoas e mercadorias se sobrepóem à geomorfologia, formando uma paisagem para muito além de modelos, que carece de um entendimento e um vocabulário próprios.

A concentraçáa de eixos viários no Centro do Rio de Janeiro ou lugares próximos explica ser este o principal polo de viagens e de oportunidades de trabalho da região (IZAGA, 2009, p. 249), onde a possibilidade de troca e opção entre diferentes modais contribuem para uma acessibilidade considerável. Conforme se distanciam da área central, as vias de trans-
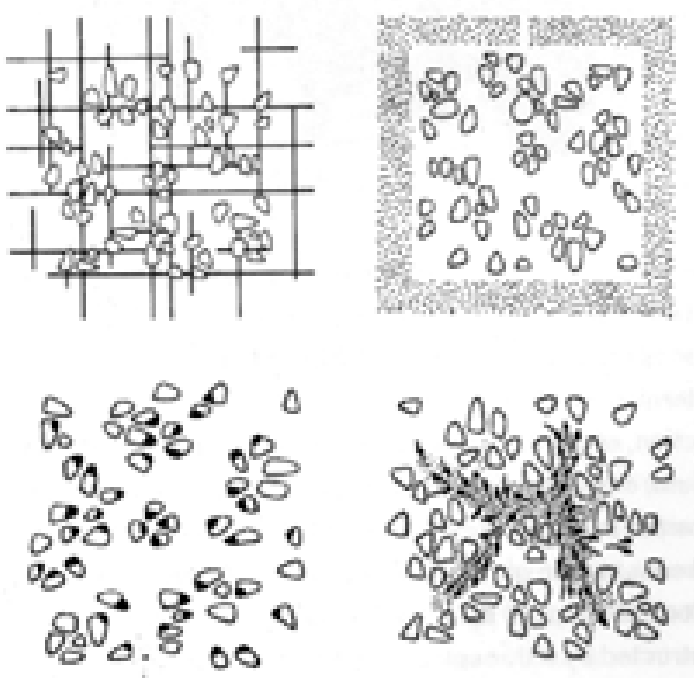

Figura 3: Fumihiko Maki e Jerry Goldberg. Mediação, definição, repetição e criação de rotas - Linkage in Collective Form 
porte se espraiam, tornando-se gradualmente mais independentes e isoladas, a despeito do fato de que se cruzam, aproximam e intersectam em momentos variados ${ }^{20}$, oferecendo oportunidades de articulação entre si e com o tecido metropolitano, a partir dos potenciais de intermodalidade e acessibilidade que sugerem (Figura 4).

Por intermodalidade entende-se a "facilidade de transição de um modo ao outro" (IZAGA, 2009, p. 31 ), o que requer alguma coesão e cooperação entre diferentes redes e modais. Por acessibilidade, entende-se "a medida da capacidade de um lugar de ser alcançado ou de alcançar" outras localidades (RODRIGUE et al., 2006, p. 28). É, portanto, um conceito relacional, que diz respeito náo apenas a distâncias ou a percursos, mas à facilidade de se chegar aonde se pretende.
Mirando contextos e paisagens do Rio de Janeiro não contidas nos ideais e padróes predominantes, situados para além do Centro ou da orla oceânica e marcados por relaçóes determinantes com a infraestrutura de mobilidade metropolitana, vejamos três exemplos interessantes e algumas características potenciais a serem exploradas. Dentre um amplo universo de oportunidades, serão brevemente analisados, à luz de ideias expostas até aqui, os seguintes espaços: uma área na regiáo do porto do Rio que não fez parte da operação Porto Maravilha; a região central do bairro de Madureira, de localização privilegiada em relação ao território metropolitano e, por fim, o bairro de Campo Grande, situado na zona oeste e principal subcentro da metrópole segundo estudo do Instituto de Estudos do Trabalho e Sociedade (2016). A opção por lugares em pontos distanciados tem a intenção

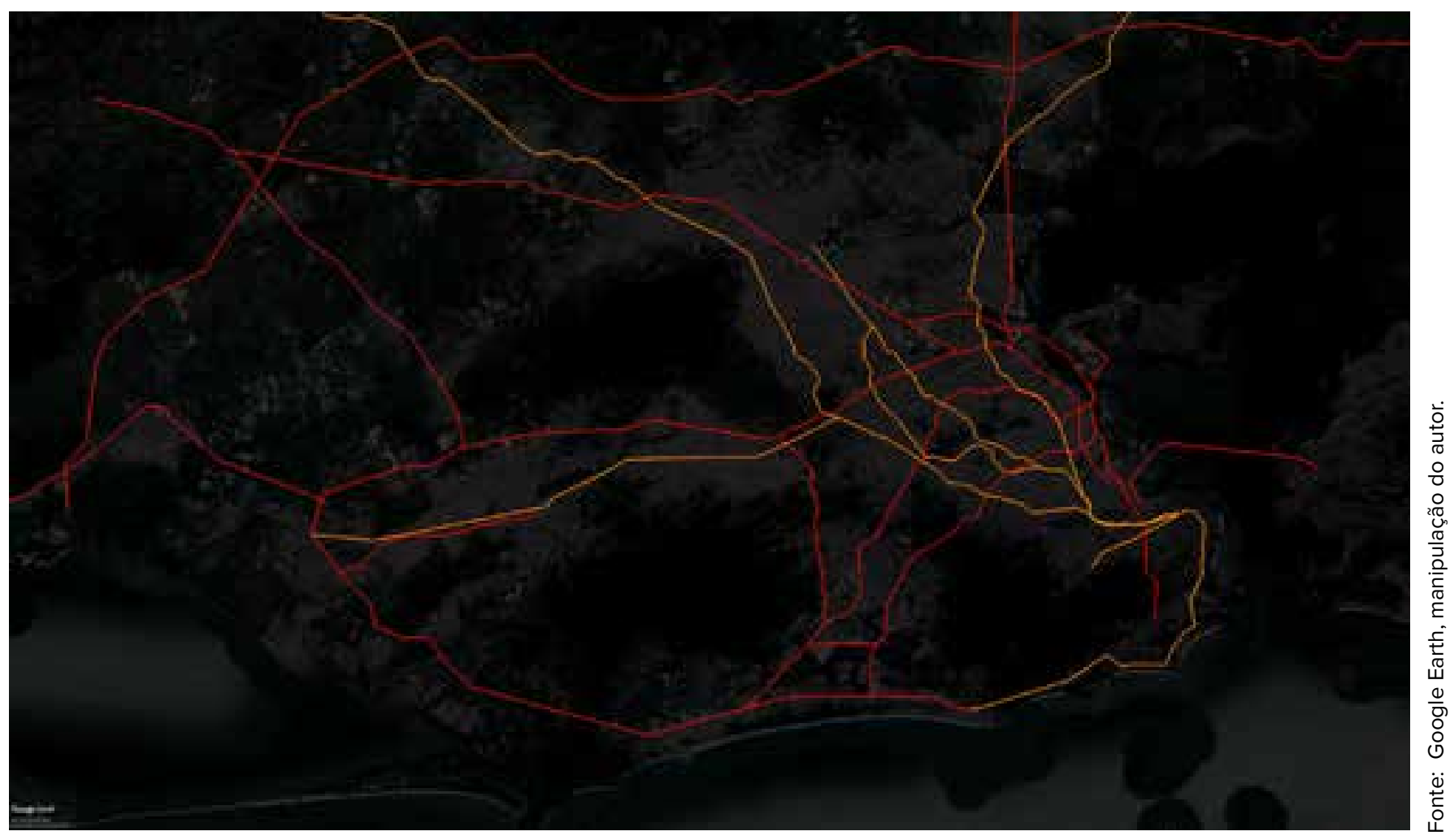

Figura 4: diagrama com rodovias (vermelho) e ferrovias (laranja), partidas do municipio do Rio. 
de ilustrar o quanto as oportunidades ensejadas por preexistências e relacionada à infraestrutura de mobilidade são variadas, se encaradas sem preconceitos e de maneira propositiva.

Junto ao segmento inicial da Avenida Brasil ${ }^{21}$, um trecho de aproximadamente $1 \mathrm{~km}$ linear oferece grande potencial urbanístico, a ser explorado com base em seu caráter metropolitano e intensa influência infraestrutural. Delimitada a sul pelas imediaçóes da rodoviária Novo Rio, avenidas Francisco Bicalho e Rodrigues Alves e a norte pelo direcionamento da própria Av. Brasil rumo a oeste; da Ponte Rio-Niterói, rumo a leste, e pelo bairro do Caju, esta área é marcada, ademais, pela, potencial, porém pouquíssimo ou nada explorada relação entre a orla da Baía de Guanabara e o tecido perpendicular do bairro de São Cristóvão. Mediada pelo cais do porto e uma faixa de terra incrustada entre a Avenida Brasil - sobreposta pelo Elevado do Gasômetro - e a Avenida Rio de Janeiro - sobreposta pelo viaduto que conduz à Ponte - a região se vê intensamente irrigada por eixos viários, recebendo fluxos contínuos de entrada e saída da cidade, em amplo contato com a Baía - que separa e pode conectar o Rio a municípios vizinhos ou maiores distâncias - além de representar enorme potencial paisagístico e ambiental. Muito próxima ao Centro, essa orla se liga diretamente a São Cristóvão, Caju e Santo Cristo, bairros de ocupação histórica e equipamentos públicos ou ocupaçóes de grande relevância para a cidade como a Estação Leopoldina, o Pavilhão de São Cristóvão, a Fundação Oswaldo Cruz, o cemitério do Caju, a Ilha do Fundão e o Mercado São Sebastião, na Penha (Figura 5).

Sua localização estratégica e conectividade dialogam com a noção de "condiçôes de campo" em escala territorial; a permeabilidade entre o tecido consolidado, os eixos rodoviários posicionados na direção norte- -sul, a plataforma do cais e o espelho d'água apontam à noção de transversalidade e ao potencial de intermodalidade de transportes, a serem possivelmente articulados à infraestrutura preexistente. Os grandes vãos, pés direitos e a robustez da infraestrutura, situada entre a plataforma das docas e grandes plantas industriais, em grande parte abandonadas, permite imaginá-la como suporte primário a transiçôes, interfaces, transposições, momentos de congestão ou conveniência, pausa ou contemplação, entre a Baía de Guanabara e o tecido consolidado da zona norte. Estes indícios, a serem decifrados e atualizados, não se enquadram nos paradigmas convencionais de cidade, mas são altamente exploráveis a partir de seu caráter metropolitano.

O bairro de Madureira (Figura 6) se destaca por abrigar intensa atividade comercial e cultural; o SESC Madureira, o Mercadão, a Portela, o Império Serrano e a CUFA (Central Única das Favelas) são exemplos de equipamentos ou instituiçóes ligadas à efervescência de um bairro marcado por "passagens e encontros" (BRITO, 2016, p. 76), dono de uma história plural e intimamente relacionada à influência das infraestruturas de mobilidade.

Situado em uma planície entre o lado oeste da Serra da Misericórdia e o limite norte do Maciço da Tijuca, Madureira conta com os ramais ferroviários de Belford Roxo e Deodoro, avenidas de fluxo intermunicipal e o corredor do BRT Transcarioca ${ }^{22}$, contíguo ao viaduto Negrão de Lima, que conecta as três partes do bairro separadas pelas linhas férreas ${ }^{23}$. Às infraestruturas de mobilidade se soma a linha de transmissáo da companhia de eletricidade do Rio de Janeiro, onde se instalou, em 2012, o Parque Madureira, "intervenção urbanística sem paralelo na história dos subúrbios da cidade" (BRITO, 2016, p. 173). 


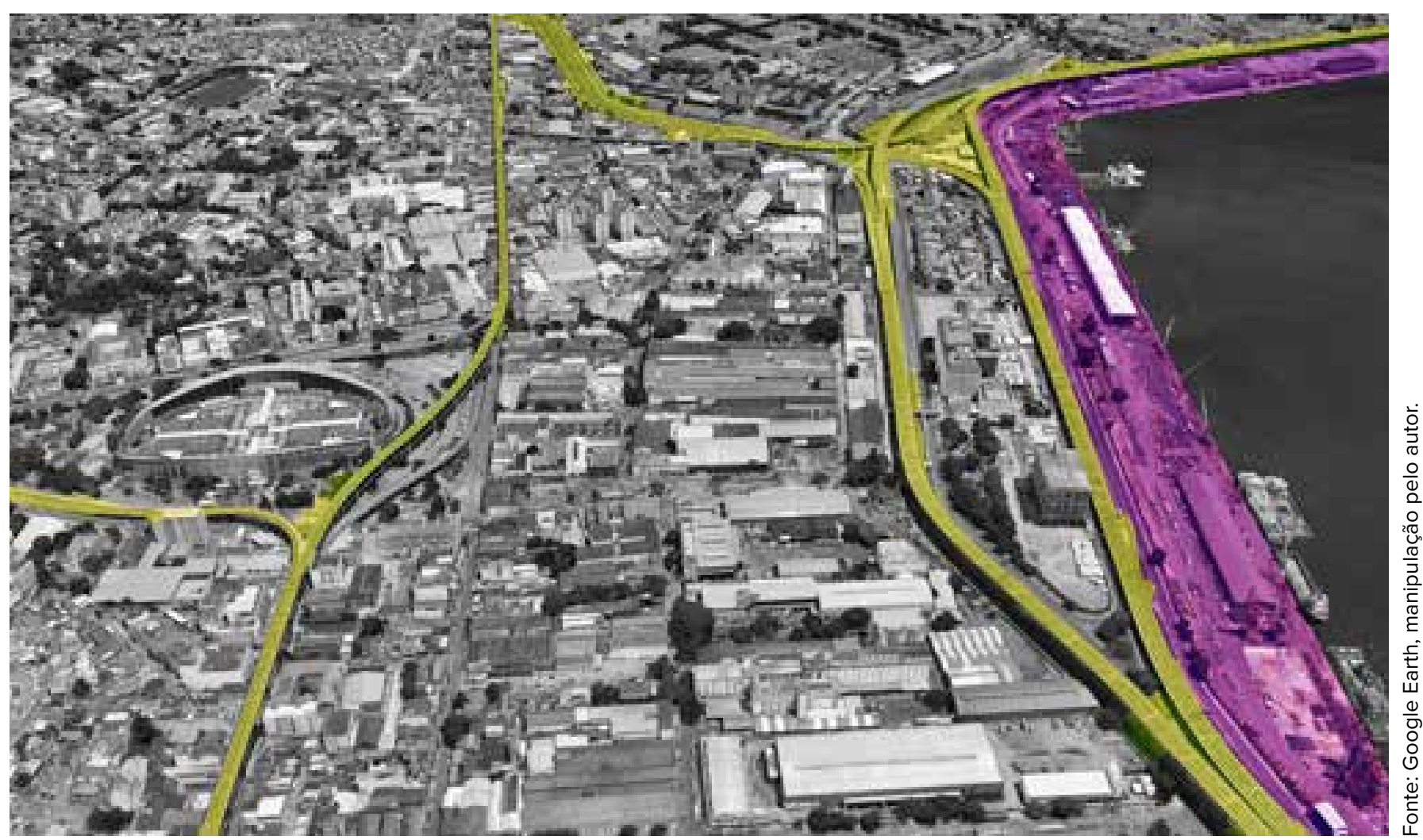

Figura 5: orla da Baía de Guanabara entre o cais do porto e São Cristóvão.

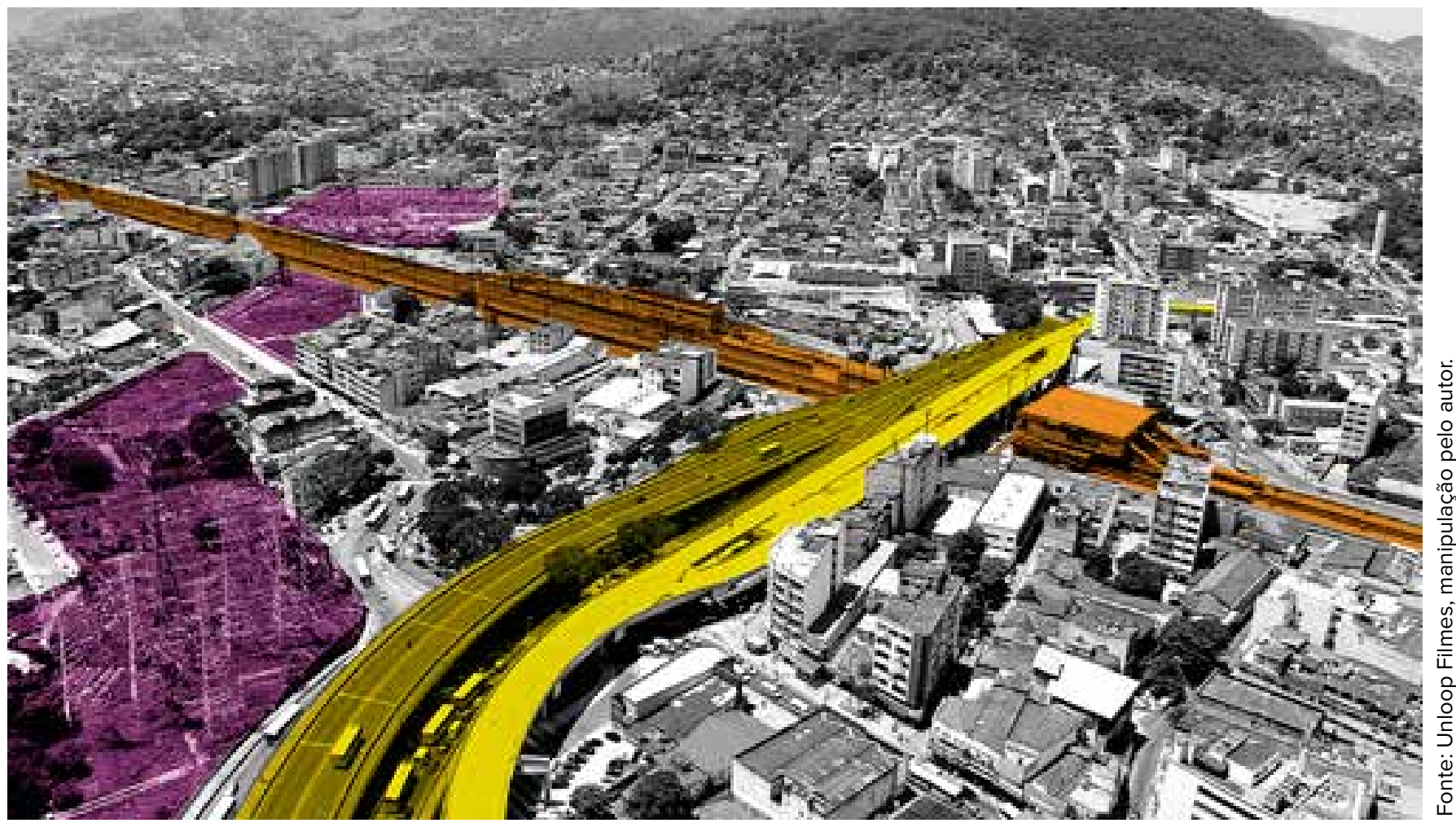

Figura 6: bairro de Madureira.

Revista online do Departamento de Arquitetura e Urbanismo da Pontifícia Universidade Católica -

Puc-Rio - Rio de Janeiro Brasil

Ano I- N I - ISSN 2446-7340 


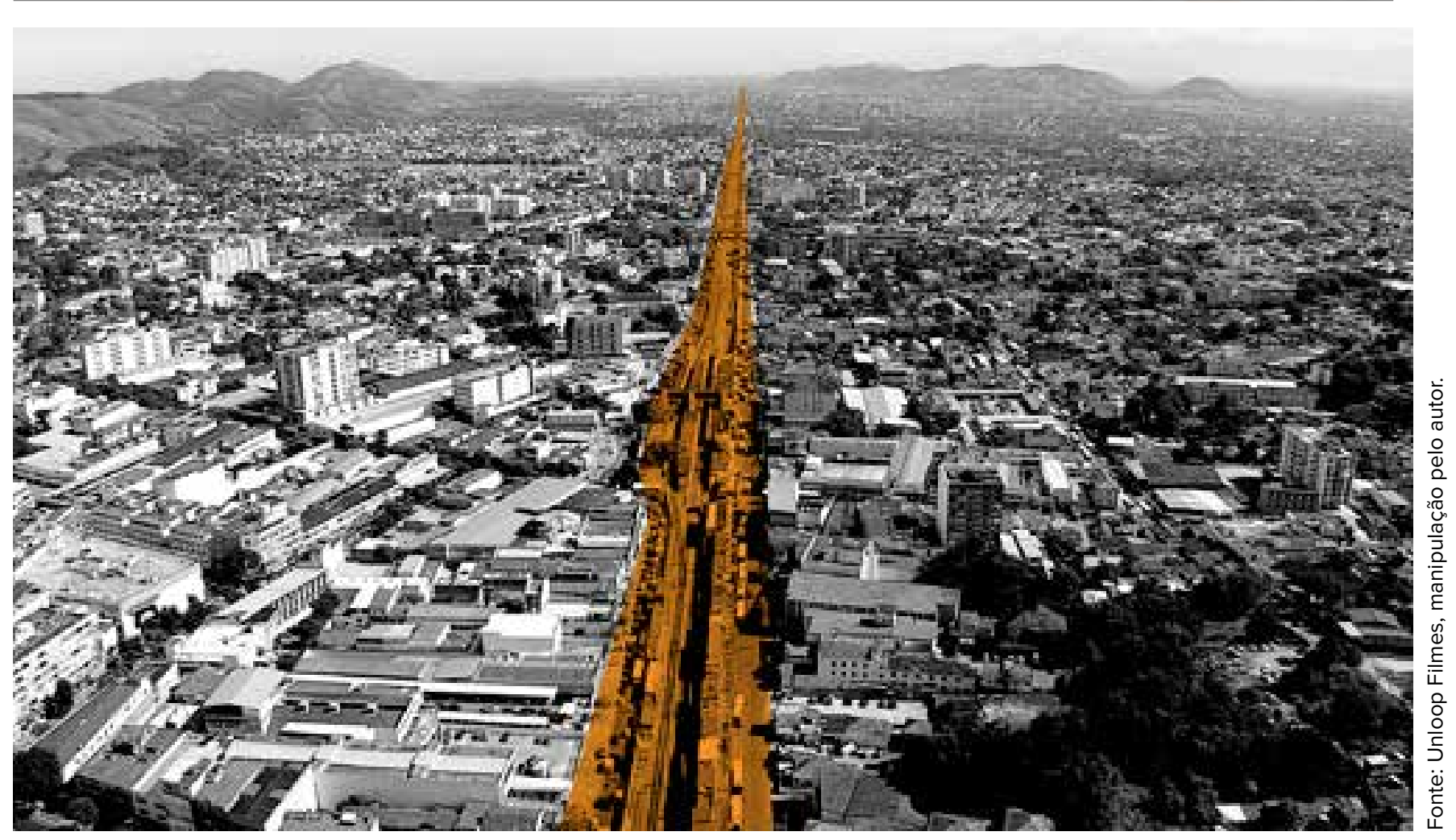

Figura 7: Campo Grande, com a linha férrea, sentido Oeste, cortando o tecido urbano.

O bairro tem, portanto, ampla conectividade a outras áreas da metrópole, o que não camufla a falta de integração, tanto operacional quanto físico-espacial, entre a malha infraestrutural e o tecido urbano. Camille Reiss (2016) demonstra o quanto a recente implantação do BRT, somada às rodovias e ferrovias preexistentes é subaproveitada, por pouco tomar partido ou reforçar o caráter policêntrico do Rio e por mal integrar as tarifas e articular os espaços entre os diferentes modais - tanto os metropolitanos quanto os mais leves e capilares. Sua análise vai além, explicitando o quanto, em escala local, o projeto arquitetônico e urbanístico das estaçôes, marcadas por grandes pórticos, amplos vãos, pés direitos, lajes e desníveis, perde a oportunidade de melhor integrar espacialmente os três trechos de bairro cortados pelas vias férreas, impede a fluidez da circulação dos pedestres, dificulta a legibilidade da transição entre os espaços e multiplica os espaços residuais já gerados pelo viaduto.
É preciso chamar a atenção para o fato de que as estações ferroviárias dos ramais Belford Roxo e Deodoro, o corredor BRT Transcarioca, o viaduto Negrão de Lima, o Mercadão de Madureira e o Parque Madureira, todos situados em raio de menos de $1 \mathrm{Km}$, coexistem de maneira pouquíssimo ou nada articulada, como camadas que se foram sobrepondo, ao longo do tempo, à pequena gramatura do bairro. Aqui faz falta um projeto que atue de forma sutil, porém ambiciosa, para fora dos parâmetros engessados de uma legislação limitadora ou de uma prática profissional complacente, intensificando os usos dos equipamentos de porte metropolitano através de sua transição a outras gramaturas e integração a outras redes e regióes, sejam de escala territorial ou local.

Campo Grande, além de principal centralidade da zona oeste, foi apontado em recente estudo do Instituto de Estudos do Trabalho e Sociedade (2016, pp. 
45-46) como mais promissor subcentro da metrópole, com base em critérios fundamentados "na concentração espacial de atividades" e na diversidade de funçôes articuladas às demais localidades do tecido metropolitano, requisitos nos quais perde em importância apenas para a área do Centro.

Desenvolvido gradativamente como um polo de comércio e serviços, o bairro se caracterizou por uma transição rural - urbana fragmentada e uma ocupação definida pela "redivisão de grandes glebas e fazendas e pelo desenvolvimento de um sistema radial a partir das estaçóes ferroviárias" (PEDROSA, 2005, p. 75) (Figura 7). Estes fenômenos resultaram em formaçóes e traçados variados dispostos de maneira fragmentada e aleatória, como indícios do que Raquel Oliveira (2014, p. 78) aponta com precisão: “a distância do Centro e a dificuldade de mobilidade associada a uma área de grande adensamento populacional motivaram a emergência" deste subcentro o que, com altos custos e saturação do núcleo metropolitano, despertou o interesse de indústrias e do mercado imobiliário sobre as terras da região, tanto em áreas próximas à estação ferroviária, quanto em partes mais remotas e de difícil acesso.

Assim, o ramal de trens de Santa Cruz e a Avenida Brasil, dispostos paralelamente no sentido leste-oeste, apesar de terem agido historicamente como principais estruturadores, não dão conta da variedade de tipologias presentes nos interstícios do bairro, que vão desde um centro incipientemente verticalizado, edifícios comerciais, loteamentos residenciais unifamiliares e condomínios de classe média a conjuntos habitacionais populares, ocupaçóes informais, áreas rurais e plantas industriais.

A implantação do BRT Transoeste ${ }^{24}$ e do Arco Metropolitano $^{25}$ reforçam a presença infraestrutural e uma potencial acessibilidade; com conexôes aos bairros da Área de Planejamento 526, Barra da Tijuca, Nova Iguaçu, Seropédica e Itaguaí, as relaçôes estabelecidas pelos grandes eixos de mobilidade permitem pensar articulaçóes perpendiculares entre eles, tomando partido de um paralelismo bastante marcante e de uma série de estaçôes de trem ou trevos rodoviários preexistentes, que podem atuar como catalisadores de intermodalidade, qualidades espaciais e atividades múltiplas.

Esta articulação pode também orientar o crescimento da área e seu potencial como centralidade sem, no entanto, permitir que o mercado ou poderes parale$\operatorname{los}^{27}$ reproduzam dinâmicas predatórias já em curso e tão vistas em outros lugares e épocas. O projeto e o desenho de transiçóes, interfaces e conexôes infraestruturais pode antecipar e potencializar momentos de intensificação e distensão, agenciando o acesso às indústrias e percursos logísticos, preservando áreas de notável caráter agrícola, estimulando o acesso às amenidades e áreas de interesse ambiental e abrindo espaço para relaçóes de produção, turismo e bem-estar da população em geral.

\section{Consideraçóes finais}

Camillo Boano propóe uma atitude ética de deslocamento perante as mecânicas do sistema produtivo, cuja materialização proporcione uma arquitetura caracterizada pela "retirada do sujeito dos aparatos existentes, os quais se apropriam de sua própria potencialidade de ser qualquer", de manifestar sua essência (2017, p. 59), direcionando-a ao uso comum e a uma outra temporalidade. Uma inversão conceitual entre figura e fundo (Figura 8$)^{28}$ pode fazer emergir, para além de "uma arquitetura de superfícies e signos" (ALLEN, 1999b, p. 51), a camada que o de- 
senho urbano insiste em afastar de suas atribuiçóes e, para longe de ações revolucionárias, ansiosas por originalidade, apontar ao aproveitamento daquilo que se pode entender como condiçáo metropolitana: uma variedade de lugares distintos e essencialmente potentes, interligados por um arcabouço que se oferece como único suporte permanente sobre o qual se pode efetivamente projetar a metrópole (FRAMPTON, 1996, p. 83).

Diferentemente de uma prática fundada sobre o “diagnóstico de problemas" e atuaçôes globais sobre o território, o infraestrutural não deve, também, associar-se necessariamente a escalas massivas, megaestruturas ou a territórios intocados, tábulas rasas. Este trabalho sugere uma alternativa ao crescimento incontrolado e escassez de parâmetros aptos a dialogar com o próprio paradigma propulsor de espraiamento e degradação urbana.

Tal atitude não procura ingenuamente negar ou combater um cenário posto, fruto de décadas de atuaçáo fragmentada do poder público no Rio de Janeiro, negligência e informalidade, mas tomar partido das oportunidades existentes, em busca de um vocabulário a partir do qual será possível alimentar estratégias de projeto voltadas a compreender e subverter escalas, mesclar e potencializar programas de acordo com um conveniente senso de oportunismo e adjacência, adensar vazios, amenizar densidades, conectar fragmentos, realçar formas indefinidas, reduzir velocidades, tensionar fluxos e desvendar o que usualmente não se vê.

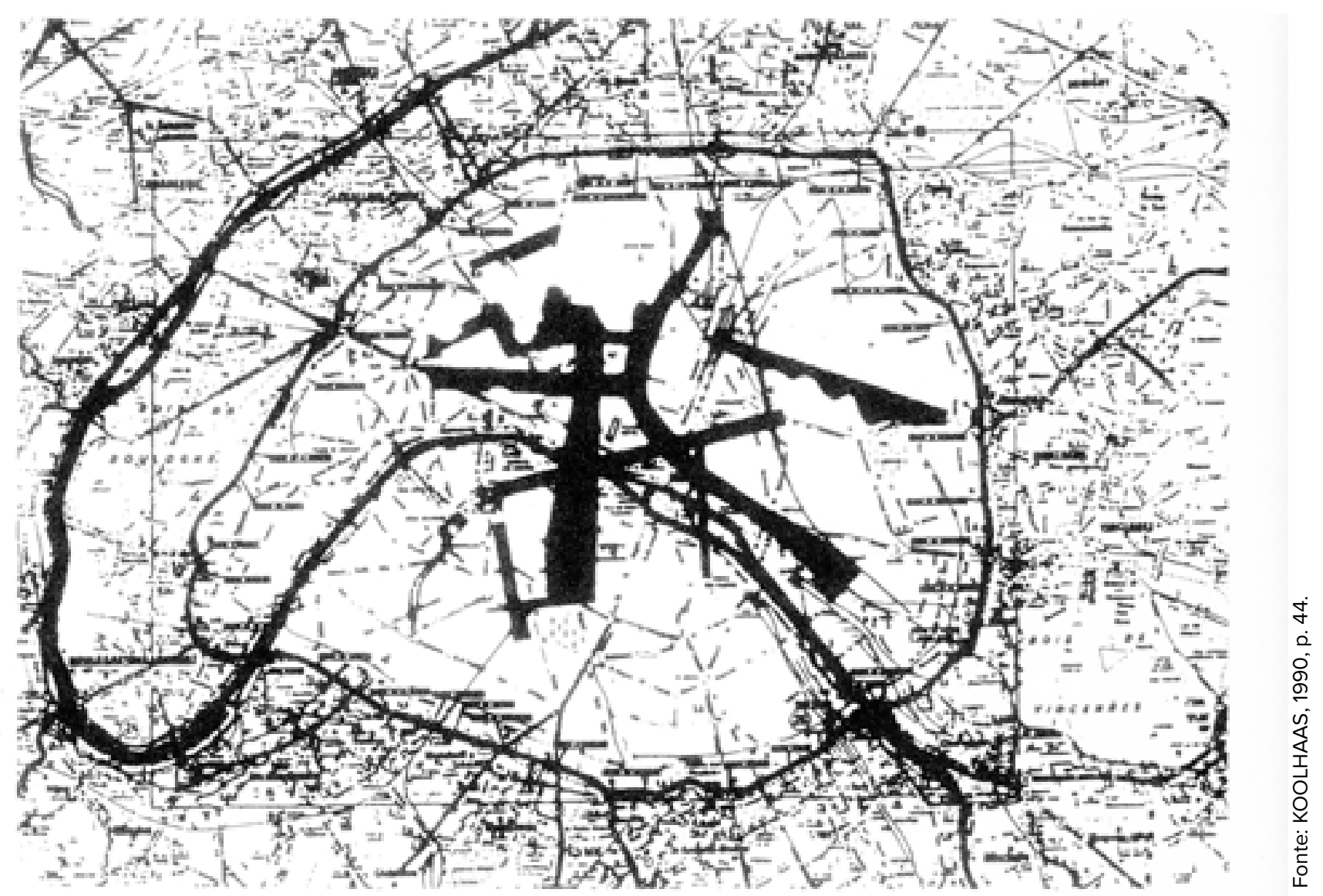

Figura 8: OMA. Melun Sènart, 1987.

Revista online do Departamento de Arquitetura e Urbanismo da Pontifícia Universidade Católica - 


\section{Notas de fim:}

1. Ocupação mais antiga da zona norte, inclui os bairros de Bonsucesso, Manguinhos, Olaria, Penha, Penha Circular, Vila da Penha, Parada de Lucas, Brás de Pina e Ramos, situados na rota da estrada de ferro Leopoldina.

2. O ladder representa o que, em português, conhecemos por "escada de marinheiro".

3. A entropia é um conceito da Física, que indica o grau de desordem entre moléculas de um sistema. Alex Wall (1999) também utiliza este termo aplicado ao urbanismo.

4. Allen afirma que a relação figura/fundo pode ser superada pela noçáo de campo, por ser este um elemento muito mais dinâmico, determinado por séries de camadas e fenômenos e não apenas um contraste bidimensional.

5. A equipe incluía os então jovens Rem Koolhaas, Peter Riemann, Hans Kolhoff e Arthur Ovaska.

6. Havia previsóes de que a população de Berlim cairia de 2.1 milhóes para menos de 1.7 milhóes na década seguinte.

7. A ideia de "cidade dentro da cidade" foi atribuída por Manfredo Tafuri ao Rockefeller Center, em Nova Iorque e aplicada por vários autores para designar o caráter dialético de partes distintas que compóem um conjunto. Além do projeto para Berlim, vale mencionar a Cidade do Globo Cativo (City of the Captive Globe), de Rem Koolhaas (1972), que, em uma malha ortogonal isotrópica, inseria arranha-céus marcados, cada um, por valores e filosofias diferenciados, formando, segundo o autor, um arquipélago que seria uma "incubadora do próprio mundo".

8. A autora relata sua pesquisa sobre processos culturais locais, comparando o caso das lonas culturais, no Rio de Janeiro, com os da friche culturelle Villa Mais d'Ici e dos Laboratoires d'Aubervilliers, no subúrbio de Paris.

9. Por ocupaçóes tradicionalmente suburbanas, refere-se a configuraçóes distanciadas de regiōes centrais, determinadas por baixa densidade, implantaçóes espaçadas e de caráter residencial essencialmente unifamiliar.

10. O estigma de periferia, a deslegitimação e o descaso não se restringem às regióes citadas, assim como há também "ilhas" ou enclaves privilegiados em meio a áreas pouco contempladas por políticas públicas ou intervençóes urbanísticas. As favelas ou ocupaçóes informais nas regióes centrais do Rio de Janeiro e de Sáo Paulo reforçam esse aspecto, demonstrando que náo se pode reduzir questóes urbanas a dicotomias. A consideraçáo de preexistências enquanto oportunidades parte justamente da premissa de que todo lugar possui certa complexidade, diferenças e conflitos em si próprio.

11. O Parque Olímpico de Deodoro se situa em meio a terrenos militares, cortado pela Avenida Brasil e próximo ao corredor BRT Transolímpico, construído para os jogos de 2016. Apesar de sua enorme área e potencial enquanto equipamento público, tem sofrido com falta de manutenção e abandono.

\section{Ver http://rionow.org/home.html}

13. Ver https://www.boston.com/cars/news-and-reviews/2015/01/05/can-we-talk-rationally-about-the-big-dig-yet

14. Exemplos amplamente conhecidos são a feira de antiguidades da Praça XV, que acontecia sob a sombra e proteção do Elevado da Perimetral e foi deslocada para uma área adjacente, porém árida, e o Baile Charme do Viaduto de Madureira, realizado aos sábados, sob o Viaduto $\mathrm{Ne}$ grão de Lima.

15. Dentre outros, Fumihiko Maki, Louis Kahn, Josep Lluis Sert, Jacquline Tyrwhitt e Sigfried Giedion. Vale mencionar, também, os membros do Team X, como Alison e Peter Smithson e Shadrach Woods.

16. Sobre estes aspectos, é interessante mencionar as siglas NIMBY (Not In My Back Yard) e LULU (Locally Unwanted Land $U_{s e}$ ), referidas a usos, atividades ou equipamentos cuja implantação supostamente produz externalidades negativas e efeitos custosos a suas adjacências. É importante notar que há diferenças e variações no entendimento dos conceitos, sobre as quais é possível encontrar revisóes e discussóes relevantes para que se as articule à prática de projeto.

17. O historiador Luiz Antônio Simas fala em uma "cultura de fresta", baseada em saberes e sociabilidades cultivados externamente aos cânones, às imposiçóes do mercado, ao controle e regulamentação institucionais e representações dominantes.

18. Os ramais da Baixada conectam a estação Central do Brasil a Paracambi, Belford Roxo, Vila Inhomirim e 
Magé, com uma bifurcação em Saracuruna. Na zona oeste, a estação de Deodoro, além de Santa Cruz, concentra e distribui grande número de viagens e passageiros. Além destas, linhas do Metrô Rio conectam o Jardim Oceânico, na Barra, ao bairro da Tijuca e à Pavuna, bairro adjacente à Baixada, passando pelas zonas sul e central.

19. Vias expressas se ligam à Ponte Rio-Niterói, Rodovia Washington Luiz (Rio-Petrópolis), à Via Dutra (Rio-São Paulo), à antiga Rio - São Paulo e à Rio Santos.

20. Os momentos e relaçóes entre os eixos a que me refiro estão, principalmente, dentro dos limites do município do Rio e boa parte deles próximos às divisas com cidades vizinhas, o que poderia representar uma considerável desconcentração de atividades, equipamentos e de foco urbanístico, voltada a localizaçôes mais acessíveis e distribuídas ao longo da área metropolitana. Há, certamente, possibilidades baseadas nos mesmos parâmetros que merecem ser buscadas e estudadas, em outros municípios, a partir de outras malhas infraestruturais e características locais.

21. Maior avenida em extensão do Brasil e o maior trecho urbano da BR-101 (Rodovia Governador Mário Covas), corta 27 bairros do Rio e liga a BR-101 norte (Ponte Rio-Niterói e Rodovia Rio-Vitória/Niterói-Manilha) à BR101 sul (Rodovia Rio-Santos), estendendo-se por mais de $58 \mathrm{~km}$.

22. Concluído em 2014, o corredor expresso conecta o aeroporto do Galeão, na Ilha do Governador, ao Terminal Alvorada, na Barra da Tijuca, ao longo de $39 \mathrm{~km}$.

23. Sob a estrutura do viaduto funciona uma das sedes da CUFA (Central Única de Favelas), com espaços e atividades de esporte, lazer e cultura; aí acontecem também os Bailes Charme do Viaduto, já tradicionais, aos sábados.

24. Inaugurado em 2012, o corredor expresso liga o Jardim Oceânico, na Barra da Tijuca, a Campo Grande, passando pelo Recreio dos Bandeirantes e Guaratiba.

25. Autoestrada que ligar o Complexo Petroquímico do Rio de Janeiro - COMPERJ, em Itaboraí, ao Porto de Itaguaí, contornando a Região Metropolitana.

26. A AP 5 engloba as regióes Administrativas de Bangu, Campo Grande, Guaratiba, Realengo e Santa Cruz e é a maior, em superfície, da cidade do Rio.

27. A zona oeste do Rio de Janeiro sofre, reconhecida- mente, a influência e a coerção de grupos paramilitares que controlam diferentes aspectos da vida urbana.

28. O projeto do OMA para a cidade nova de Melun-Sénart (1987), na periferia de Paris, se utiliza deste procedimento, ao projetar espaços livres de estruturação urbana flexível, que permitem, nas áreas a serem ocupadas e construídas, formas diversas, mutáveis, adaptáveis à passagem do tempo e renovaçôes técnicas.

\section{Referências Bibliográficas:}

ALLEN, S. Field Conditions. In: ALLEN, S. Points + Lines: Diagrams and Projects for the City. New York: Princeton Architectural Press, 1999a. p. 90 - 103.

Infrastructural Urbanism. In: $A L$ LEN, S. Points + Lines: Diagrams and Projects for the City. New York: Princeton Architectural Press, 1999b. p. 46 $-57$.

Landscape Infrastructures. In: STOLL, K.; LLOYD, S. Infrastructure as Architecture. Designing Composite Networks. Zurich: ETH, 2010. p. 36-45.

AURELI, P. V. The Possibility of an Absolute Architecture. Cambridge: MIT Press, 2011.

The Common and the Production of Architecture: early hypotheses. In: CHIPPERFIELD, D.; LONG, ; BOSE, S. Common Ground: A Critical Reader. Venice: Marsilio, 2012.

Habitando la Abstracción: Notas a Ladders, de Albert Pope. In: POPE, A. Ladders. Princeton Architectural Press: New York, 2015.

BOANO, C. Una Arquitectura Cualquiera. ARQ DOCS: Santiago de Chile, 2017.

BRITO, J. F. P. A Construção Estratégica do Bairro Madureira na Cidade Olimpica: novas espacialidades, temporalidades e conflitos no Rio de Janeiro dos megaeventos. Tese de doutorado - Instituto de Filosofia e Ciências Sociais - UFRJ. Rio de Janeiro. 2016.

D'HOOGHE, A. The Liberal Monument: a definition of urban design as the manifestation of romantic late-modernism. Tese de doutorado - Universidade de Delft. 2007. 
The Liberal Monument: Urban Design and The Late Modern Project. New York: Princeton Architectural Press, 2010.

FARIAS FILHO, J. A. O Projeto Urbano Ex-Cêntrico como Instrumento de Política Metropolitana. In: COSTA, L. M. S. A.; MACHADO, D. B. P. Conectividade, Resiliência: estratégias de projeto para a metrópole. Rio de Janeiro: Rio Books, 2012. p. 31-61.

FEFERMAN, C. E. A Cidade Linear: representaçóes de um modelo no início do século $X X$. Tese de doutorado PROURB, UFRJ. Rio de Janeiro. 2007.

FERNANDES, N. D. N. O Rapto Ideológico da Categoria Subúrbio: Rio de Janeiro 1858/1945. Rio de Janeiro: Apicuri, 2011.

FERRÁN, M. De Bangu a Aubervilliers: Politica Cultural $e$ Gestão Urbana Contemporâneas. Revista da FAU UFRJ, Rio de Janeiro, v. n.2, p. 90-99, 2009.

FRAMPTON, K. Megaforma e relevo como uma estratégia possível.Tradução de Anete Araújo. RUA - Revista de Urbanismo e Arquitetura, Salvador, v. 4, p. 80-85, 1996. Disponivel em: <https:/portalseer.ufba.br/index.php/ rua/issue/view/349/showToc>. Acesso em 20/08/2018.

HAUCK, T.; KLEINEKORT, V. Infrastructural Urbanism. Adressing the In-between. In: HAUCK, T.; KELLER, R.; KLEINEKORT, V. Infrastructural Urbanism: Adressing the In-between. Berlim: DOM Publishers, 2011. p. 9-17.

HERTWECK, F.; MAROT, S. The City in the City: Berlin: A Green Archipelago. Zurich: Lars Müller Publishers, 2013.

INSTITUTO DE ESTUDOS DO TRABALHO E SOCIEDADE. Centralidades da Regiāo Metropolitana do Rio de Janeiro: Relatório Final. Rio de Janeiro: IETS, 2016.

IZAGA, F. Mobilidade e Centralidade no Rio de Janeiro. Tese de doutorado - PROURB, UFRJ. Rio de Janeiro. 2009.

KONDER, L. A Questão da Ideologia. São Paulo: Companhia das Letras, 2002.

KOOLHAAS, R. Rem Koolhaas: Projectes urbans (19851990). Barcelona: Collegi d'arquitectes de Catalunya, 1990.
. Nova York Delirante: Um Manifesto Retroativo para Manhattan. São Paulo: Cosac Naify, 2008.

LASSANCE, G. Sobre a oportunidade de um legado olímpico para o Rio. Prumo, Rio de Janeiro, n. 3, p. $76-$ 85, 2017.

LASSANCE, G.; ENGEL, P. Da Composição de Agendas no Ensino de Projeto. IV ENANPARQ - Encontro da Associação Nacional de Pesquisa e Pós-Graduação em Arquitetura e Urbanismo, Porto Alegre, p. 1-14, 25-29 Julho 2016.

LASSANCE, G.; IZAGA, F. Antigos Subúrbios, Novas Periferias: A Questão Territorial do Projeto. Revista da FAU UFRJ, Rio de Janeiro, v. n. 2, p. 52-57, 2009.

LINS, A. J. S. P. Subúrbios e Periferia: a ferrovia na construção da região metropolitana do Rio de Janeiro. Revista da FAU UFRJ, Rio de Janeiro, v. n.2, p. 16-25, 2009.

MAKI, F.; GOLDBERG, J. Linkage in Collective Form. In: MAKI, F.; GOLDBERG, J. Investigations in collective form. Washington: St. Louis, School of Architecture, Washington University, 1964. p. 25-52.

NOBRE, A. L. Notícias de uma cidade preolímpica. PLOT, Buenos Aires, v. n. 26, p. 166-181, 2015.

OLIVEIRA, M. P. D. Prefácio. In: FERNANDES, N. D. N. O Rapto Ideológico da Categoria Subúrbio: Rio de Janeiro 1858 - 1945. Rio de Janeiro: Apicuri, 2015. p. 11-13.

OLIVEIRA, R. D. L. Centralidade na Periferia: a centralidade de Campo Grande na zona oeste da metrópole carioca. Dissertação de Mestrado - Programa de Engeharia Urbana - Escola Politécnica UFRJ. Rio de Janeiro. 2014.

PEDROSA, A. R. Paisagem, Sistema, Lugar: sistemas de lugares nas praças de Campo Grande. Dissertaçấo de mestrado - PROURB UFRJ. Rio de Janeiro. 2005.

POPE, A. Ladders. New York: Princeton Architectural Press, 1996.

RAMÍREZ, F. R. Un entendimiento infraestructural del proyecto arquitectónico. Tese de doutorado - Escuela Técnica Superior de Arquitectura de Madrid. 2015.

REISS, C. M. Infraestrutura de Transporte, Vetor de Urbanidade: o corredor expresso de ônibus (BRT) em Madurei$r a$, Rio de Janeiro. PPGArq - PUC-Rio. Rio de Janeiro. 2016. 
RODRIGUE, J. P.; COMTOIS, C.; SLACK, B. The Geography of Transport Systems. New York: Routledge, 2006.

SEBRAE. Mobilidade Urbana e Mercado de Trabalho na Região Metropolitana do Rio de Janeiro. Rio de Janeiro. 2013.

SHOSHKES, E. Jacqueline Tyrwhitt and Transnational Discourse on Modern Urban Planning and Design, 19411951. Urban History, Cambridge, v. 36, n.2, p. 262-283, 2009.

SIMAS, L. A. Dos Arredores da Praça Onze aos Terreiros de Oswaldo Cruz. Revista Z Cultural, Rio de Janeiro, n. Ano XI / 01, 2016. ISSN ISSN 1980 9921. Disponivel em: <http://revistazcultural.pacc.ufrj.br/?ano=42\&edi$\mathrm{cao}=43>$. Acesso em 20/08/2018.

SOLÀ-MORALES, I. D. Terrain Vague. Territorios, Barcelona, p. 123-132, 2002.

SOLOMON, J. D. 13 Projects for the Sheridan Expressway. New York: Princeton Architectural Press, 2004.

TORRES, P. H. C. Uma Avenida Chamada Brasil: expansão e consolidação do Rio de Janeiro suburbano. Tese de Doutorado - PPGCIS - PUC. Rio de Janeiro. 2017.

TZONIS, A.; LEFAIVRE, L. Beyond Monuments, Beyond Zip-a-tone. Shadrach Woods's Berlin Free University, a Humanist Architecture. Le Carré Bleu, Helsinque, v. n. 4, p. 4-43, 1998.

VILLAÇA, F. Espaço intra urbano no Brasil. São Paulo: Studio Nobel: FAPESP: Lincoln, 2001.

WALL, A. Flow and interchange: mobility as a quality of urbanism. In: SOLÀ-MORALES, I. D.; COSTA, X. $A r-$ chitecture in Cities: Present and Future. Barcelona: Centre de Cultura Contemporània de Barcelona, 1996.

WERTHMANN, C. Squatting Infrastructure. In: HAUCK, T.; KELLER, R.; KLEINEKORT, V. (. ). Infrastructural Urbanism: Adressing the In-between. Berlin: DOM Publishers, 2011. p. 289-301.

WOODS, S. The Man In The Street: A Polemic on Urbanism. London: Penguin Books, 1975. 